\title{
$\mathrm{CFRP}$ 판 보강 RC보의 균열 및 박리 손상 모니터링
}

\section{Crack and Debonding Donitoring of RC Beams Strengthened with CFRP Plates}

$\begin{array}{cccc}\text { 윤 준 호 }^{1)} & {\text { 한 정 } \text { 헌 }^{2)}}_{\text {조 두 용 }}^{3) \star} & \text { 박 선 규 }^{4)} \\ \text { Yoon, Jun Ho } & \text { Han, Jung Hun } & \text { Cho, Doo Yong } & \text { Park, Sun Kyu }\end{array}$

\section{Abstract}

A CFRP (Carbon Fiber-Reinforced Plastic) strengthening method being widely used to increase the load-carrying capacity of structures is very suitable for existing bridge structures. However, not only flexure and shear failures but also debonding failure might be additionally occured in reinforced concrete(RC) beams strengthened with the CFRP plates. The CFRP debonding failure would cause a brittle fracture of the beam. Therefore, health monitoring for the CFRP bonding condition is strongly required. In this study, a feasibility of the impedance-based damage detection method using PZT sensors was investigated through a series of experimental studies for realtime structural health monitoring (SHM) for the CFRP laminated concrete structures.

Keywords : Crack, Debonding, CFRP, Helath monitoring, Impedance method

\section{1. 서 론}

보수보강된 구조물은 기존 설계 시 예측되었던 파괴모 드가 변화하게 된다. 이러한 변화는 결국 구조물의 예측 가능한 파괴 경향을 파악하기 어렵게 하는 중요한 변수가 된다. 따라서 보수보강된 구조물은 변화된 파괴모드를 고 려한 실시간 상시계측을 통하여 구조물의 이상 거동을 감 지하고, 적절한 유지관리를 도모함으로써 시설물의 붕괴 를 미연에 방지해야 한다(류성찬 등 2010).

사회기반 시설물의 효율적인 건전성 모니터링을 위해 최근 많은 연구가 이루어지고 있다. 특히 IT기반 스마트 센서 및 이를 이용한 스마트 모니터링 기술은 국부적인 손상의 추정에 유리한 기법으로 보수보강된 구조물에 적 용하는데 있어 효율적인 기법이다.(이진학 등, 2004)

스마트 센서를 이용한 구조물의 손상 모니터링 방법에 관한 연구는 미국, 일본 등의 선진국에서는 이미 꾸준히 진행되어 왔으나 계측 데이터를 이용하여 구조물의 손상 상태를 정량적으로 평가하는 것이 어렵고 구조물의 특성 에 맞는 측정과 평가방법에 대한 기준이 확립되지 않아

1) 학생회원, 성균관대학교 u-City공학과 석사과정

2) 학생회원, 성균관대학교 u-City공학과 석사과정

3) 정회원, 성균관대학교 건설환경시스템공학과 연구교수

4) 정회원, 성균관대학교 건설환경시스템공학과 정교수
실용화 단계까지 발전하지 못하고 있는 상태이며 이를 보 안하기 위한 연구가 활발히 진행되고 있다. 스마트 센서 로 사용되는 압전소자는 B. Jaffe(1950)에 의해 온도, 습 도의 변화와 시간 경과에 대해 안정된 재료 특성을 가지 며, 이후에 압전성이 우수한 PZT(Piezo-electric) 계 압 전 세라믹스가 발견됨에 따라 본격적으로 개발되기 시작 하여 임피던스 기반 구조물의 검색 기법(Giurgiutiu (1999)), 전자파를 이용한 구조물 검색 기법(Kessler (2002)) 등을 이용한 구조물 손상검색 기법 개발에 관한 연구와 계측된 신호처리 기법(Sohn and Farrar(2001)) 과 신호 패턴인식(Farrar(2000)을 통한 구조물의 손상 도 평가에 관한 연구가 지속적으로 진행되어 왔다.

한편, 국내에서는 박승희 등(2005)이 압전센서를 이용한 구조물 건전성 평가에 관한 연구를 수행하였으며 지능형 센 서 중의 하나인 PZT센서를 이용하여 알루미늄, 강재 및 콘 크리트의 균열손상, 강재의 볼트 풀림 등의 손상 모니터링 실험을 수행하여 모니터링 기법 검증 및 적용 방법을 제시하 였다. 또한 홍용(2009)은 PZT 센서를 이용하여 구조물의 손상의 크기와 위치에 따른 임피던스 파형의 관계를 조사하

\footnotetext{
* Corresponding author : dooyongcho@skku.edu 031-290-7530

- 본 논문에 대한 토의를 2011년 7월 31일까지 학회로 보내주시면 2011년 9월 호에 토론결과를 게재하겠습니다.
} 
였고 손상평가지수로 임피던스 피크의 쉬프트 량을 사용하여 손상정도를 파악하였으며 김대민(2008)은 PZT센서를 이용 한 Coherence기반 비파괴 검사기법을 콘크리트 구조물의 손상 모니터링에 적용해 검사기법을 제안하고 평가하였다.

본 연구에서는 실제 교량에 적용빈도가 높고 활용성에

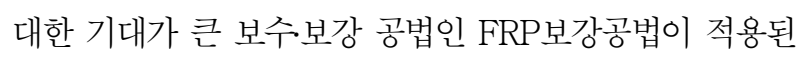
구조물에 PZT센서를 이용한 손상 모니터링 기법에 대한 적용 방법을 연구하기 위한 목적으로 수행되었다. 구조물 에 $\mathrm{FRP}$ 보강공법이 적용되면 변화하는 파괴모드로 인해 파괴거동을 파악하기 어렵게 된다. 효율적인 손상 모니터 링을 위하여 $\mathrm{RC}$ 보의 파괴양상을 파악하였으며 적절한 센서 위치와 계측 시 주목해야할 부분을 결정하였다.

또한 본 실험에서는 철근콘크리트 보 실험체를 제작하 여 CFRP 판보강을 실시하였으며. 하중단계 별로 임피던 스를 측정하였다. 이를 통해 $\mathrm{FRP}$ 로 보강된 철근콘크리트 보의 국부적 및 전체적인 거동을 분석하여 FRP보강 공법 이 적용된 구조물의 손상 모니터링 기법에 대하여 임피던 스를 기반으로 한 PZT센서의 적용성을 검토하고 모니터 링 방법에 대해 고찰을 수행하였다.

\section{2. 손상 검색 기법}

\section{1 임피던스 기반 손상 검색 기법}

구조물에 부착된 지능형 센서인 PZT센서를 고주파영 역에서 가진 후에 구조물-PZT센서의 전기-역학적 임피 던스를 측정함으로써, 손상 전후의 임피던스 신호변화를 모니터링하여 손상정도를 추정하는 기법이 임피던스 기 반 손상 검색 기법이다.

임피던스 기법은 구조물의 재료특성, 형상 및 질량 그 리고 온도, 손상의 종류 등 다양한 인자에 따라 임피던스 신호의 변화양상이 달라기 때문에 정량적인 평가 기준을 확립하기 어렵다. 따라서 실 구조물에 적용을 위해서는 먼저 대상 구조물의 거동을 미리 파악하여 위험 구간에서 의 국부적인 손상 모니터링을 통하여 구조물의 건전성을 파악하는 것이 효율적인 방법이라 할 수 있다. 그리고 무 손상 상태에서 구조물-PZT센서의 전기-역학적 임피던 스의 영향을 주는 인자들을 확인하고 그런 인자들로 인한 임피던스의 변화양상을 파악해야 한다.

특히, 실제 교량구조물은 교통하중 등에 의해 콘크리트 및 FRP에 변형 및 진동이 발생하기 때문에 임피던스의
패턴을 분석하고 손상지수의 변화량의 파악이 선행되어 야 하며 이러한 인자들의 영향을 보정하거나 기본 오차율 로 가정하여 손상으로 인한 임피던스 신호의 변화만을 구 분할 수 있는 기초를 마련하여야 한다.

본 실험에서는 $\mathrm{CFRP}$ 로 보강된 콘크리트 보에 하중을 주어서 균열이 발생하거나 $\mathrm{CFRP}$ 의 박리를 임피던스의 신호변화에 어떤 영향을 끼치는지를 통하여 손상정도를 확인하고자 한다.

지능형 센서인 PZT센서가 구조물에 부착되었을 때 구 조물-PZT센서의 전기-역학적 임피던스(EMI : Electro-Mechanical Impedance)는 식 (1), (2)와 같 이 표현된다(Liang et al, 1994).

$$
\begin{aligned}
& Z_{\text {total }}(\omega)^{-1} \\
& =i \omega \frac{w l}{h} \overline{\varepsilon_{33}^{T}}-d_{31}^{2} \overline{Y^{E}}+\left(\frac{Z_{a}(\omega)}{Z_{s}(\omega)+Z_{a}(\omega)}\right) d_{31}^{2} \overline{Y^{E}}\left(\frac{\tan \kappa l}{\kappa l}\right) \\
& =G(\omega)+i B(\omega)
\end{aligned}
$$

위 식에서 $w, l, h: \mathrm{PZT}$ 센서의 폭, 길이, 두께이며 $\overline{\varepsilon_{33}^{T}}$ 은 일정한 응력상태에서의 PZT 센서의 유전율, $d_{31}$ 은 압 전상수, $\overline{Y^{E}}$ 은 PZT센서의 Young's modulus, $\kappa$ 는 파수 (wave number), $Z_{s}(\omega)$ 와 $Z_{a}(\omega)$ 는 각각 구조물과 PZT센서의 임피던스를 의미한다.

구조물과 PZT센서의 전기-역학적 임피던스는 식 (2) 와 같이 $G(\omega)$ (실수부)와 $B(\omega)$ (허수부)로 표현될 수 있으며 Bhalla et al (2002)에 의해 구조물의 손상 변화 에 대해 임피던스의 실수부가 허수부에 비해 더욱 민감하 게 반응함이 증명되었다.

\section{2 공진주파수를 이용한 손상지수(RMSD : Root Mean Square Deviation) 방법}

앞에서 언급된 임피던스 기반 구조 손상 검색 기법은 얼마나 손상이 되었는지에 대해서 정량화되어 있지 않아 서 신뢰성을 얻기에는 역부족이다. 임피던스 기반 구조 손상 검색 기법은 구조물의 균열 등 손상에 의한 역학적 임피던스라는 구조물의 고주파 동적응답인 구조물-센서 시스템의 EMI 변화를 사용하여, 측정주파수 영역에서 임 피던스 신호의 크기뿐 아니라 공진주파수의 변화까지도 동시에 손상을 감지할 수 있기에, 구조 손상의 정량화를 위해 식 (3)에서와 같이 표현되는 RMSD (Root Mean 
Square Deviation) 값을 변량/Intact(무 손상상태)에 대 입하여 손상지수로 이용한다.

$$
\operatorname{RMSD}(\%)=\sqrt{\frac{\sum_{i=1}^{n}\left\{\operatorname{Re}\left(Z_{i .1}\right)-\operatorname{Re}\left(Z_{i .0}\right)\right\}^{2}}{\sum_{i=1}^{n}\left\{\operatorname{Re}\left(Z_{i .0}\right)\right\}^{2}}}
$$

여기서, $\operatorname{Re}\left(Z_{i .0}\right)$ 와 $\operatorname{Re}\left(Z_{i .1}\right)$ 은 각각 손상 전 (Baseline)과 손상 후를 의미한다. 임피던스 신호의 실수 부를 의미하고, RMSD 손상지수를 사용할 때, 손상의 유 무를 판단하는 기준이 되는 임계값 설정이 필요하며 이 임계값은 outlier analysis 를 이용하여 결정한다. (Park. G et al, 2001, 2003).

임피던스 응답특성 분석기법으로서는 임피던스 응답 상 관계수 분석법, 임피던스 제곱근오차(Root Mean Square Deviation, RMSD) 분석법, 공진주파수(Resonant Fequency) 변화 분석법 등이 있다. 이정미(2008)는 $\mathrm{RMSD}$ 기법의 결과가 앞선 기법들에 비해 더 선형적으로 나온 것을 확인하였으며 이는 추후 모니터링에 있어 $\mathrm{RMSD}$ 분석기법을 이용할 경우 가장 정확한 측정을 할 수 있을 것으로 판단하였다. 따라서 본 논문에서는 RMSD 기 법을 사용하여 임피던스 변화를 관찰하였다.

\section{3. 실험 연구}

\section{1 실험체 제작 및 실험 방법}

보강실험을 위해 단면치수 $200 \times 300 \mathrm{~mm}$, 피복두께

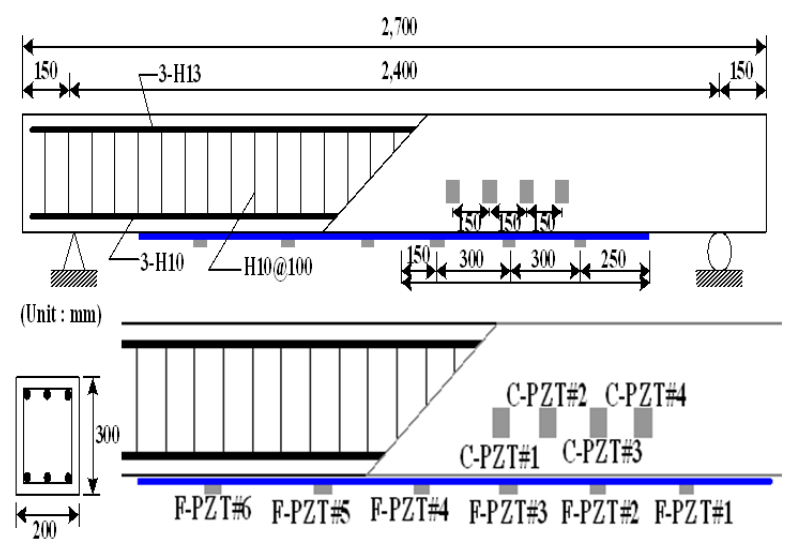

Fig. 1 Specification of specimen and Positions of PZT (Piezo-electric) sensors
$30 \mathrm{~mm}$, 실험체 총 길이 $2700 \mathrm{~mm}$, 순지간 길이 $2400 \mathrm{~mm}$ 인 콘크리트 보를 제작하였다. 휨파괴 및 부착파괴를 유 도하기 위해 인장 측에는 $\mathrm{H} 10$ 철근을 사용하였으며, 압 축 측에는 $\mathrm{H} 13$ 철근을 사용하였다. 휨 균열에 대한 모니 터링을 용이하게 하기 위하여 압축철근을 더 많이 사용하 였다. 스터럽은 $\mathrm{H} 10$ 철근을 사용하였으며 $100 \mathrm{~mm}$ 간격 으로 배치하였다. CFRP 판은 길이 $2000 \mathrm{~mm}$, 폭 $50 \mathrm{~mm}$ 로 콘크리트 보의 하면에 에폭시를 사용하여 부착하였다. $\mathrm{CFRP}$ 박리를 모니터링 하기 위하여 CFRP 하면에 $30 \mathrm{~cm}$ 간격으로 $35 \mathrm{~mm} \times 35 \mathrm{~mm}$ 크기인 6 개의 지능형 센서인 PZT를 부착하였고, 콘크리트의 휨 균열에 대한 모니터링 을 위하여 집중 휨 균열이 발생하는 하중 재하 지점으로 부터 각각 $7.5 \mathrm{~cm}, 22.5 \mathrm{~cm}, 37.5 \mathrm{~cm}, 52.5 \mathrm{~cm}$ 떨어진 지 점에 $35 \mathrm{~mm} \times 35 \mathrm{~mm}$ 크기인 4 개의 지능형 센서인 $\mathrm{PZT}$ 를 부착하였다. 본 실험을 위하여 제작된 실험체의 형상 과 상세도 및 PZT센서 부착 위치는 Fig. 1과 같으며 재 료 물성은 Table 1 Table 4와 같다.

아래의 Photo 1 은 하중재하 및 임피던스 계측 장비를 보여주고 있다. $1000 \mathrm{kN}$ 용량의 UTM으로 4점 재하 정

Table 1 Property of concrete(28-day strength)

\begin{tabular}{c|c|c|c}
\hline $\begin{array}{c}\text { Specified } \\
\text { compressive } \\
\text { strength } \\
(\mathrm{MPa})\end{array}$ & $\begin{array}{c}\text { Tensile strength } \\
(\mathrm{MPa})\end{array}$ & $\begin{array}{c}\text { Compressive } \\
\text { strength } \\
(\mathrm{MPa})\end{array}$ & $\begin{array}{c}\text { Modulus of } \\
\text { elasticity } \\
(\mathrm{MPa})\end{array}$ \\
\hline 24 & 2.3 & 25.2 & $2.16 \times 10^{4}$ \\
\hline
\end{tabular}

Table 2 Property of Rebar

\begin{tabular}{c|c|c|c|c}
\hline Type & $\begin{array}{c}\text { Yield strength } \\
(\mathrm{MPa})\end{array}$ & $\begin{array}{c}\text { Tensile } \\
\text { strength } \\
(\mathrm{MPa})\end{array}$ & $\begin{array}{c}\text { Modulus of } \\
\text { elasticity } \\
(\mathrm{MPa})\end{array}$ & $\begin{array}{c}\text { Elongation } \\
(\%)\end{array}$ \\
\hline H10 & 472.3 & 725.2 & $2.01 \times 10^{5}$ & 14.4 \\
\hline H13 & 452.6 & 698.3 & $2.11 \times 10^{5}$ & 17.2 \\
\hline
\end{tabular}

Table 3 Property of CFRP

\begin{tabular}{c|c|c|c|c|c}
\hline Type & $\begin{array}{c}\text { Width } \\
(\mathrm{mm})\end{array}$ & $\begin{array}{c}\text { Thickness } \\
(\mathrm{mm})\end{array}$ & $\begin{array}{c}\text { Tensile } \\
\text { strength } \\
(\mathrm{MPa})\end{array}$ & $\begin{array}{c}\text { Tensile } \\
\text { modulus of } \\
\text { elasticity } \\
(\mathrm{MPa})\end{array}$ & Note \\
\hline Plate & 50 & 1.2 & over 3,000 & $1.5 \times 10^{5}$ & SK-CPS 05 \\
\hline
\end{tabular}

Table 4 Property of Epoxy

\begin{tabular}{c|c|c|c|c}
\hline Type & $\begin{array}{c}\text { Dry time } \\
(\mathrm{hr})\end{array}$ & $\begin{array}{c}\text { Bond strength } \\
(\mathrm{MPa})\end{array}$ & $\begin{array}{c}\text { Compressive } \\
\text { strength } \\
(\mathrm{MPa})\end{array}$ & Note \\
\hline epoxy & within 11 & 2 & 35 & epoxy putty \\
\hline
\end{tabular}




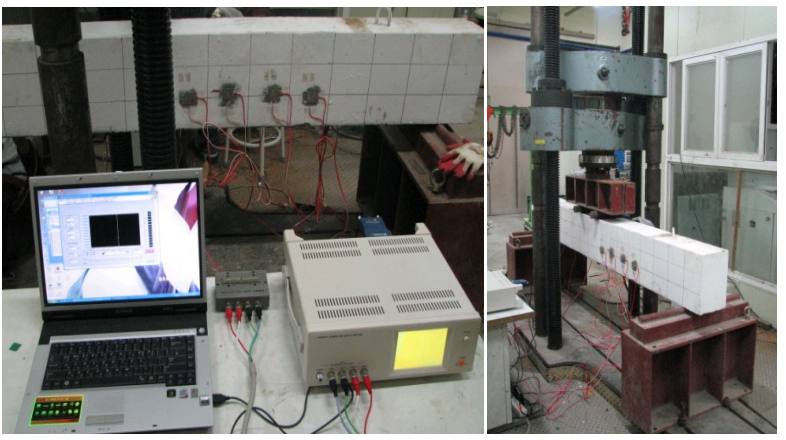

Photo 1 Experimental set up for concrete crack monitoring and concrete beam loading

적 휨 실험을 실시하였고 PZT 센서의 임피던스 신호는 $22.54 \mathrm{kN}$ (균열하중), $38.2 \mathrm{kN}, 58.5 \mathrm{kN}, 76.44 \mathrm{kN}$ (CFRP 탈락), $\mathrm{CFRP}$ 탈락이후 주요균열 $2 \mathrm{~mm}$ 정도로 확장되었을 때 계측하였다. $38.2 \mathrm{kN}$ 과 $58.5 \mathrm{kN}$ 은 균열 변화가 육안 상으로 확연히 드러나는 시점이다. 계측을 위해 LCR 하 이테스터를 사용하여 임피던스를 계측하였으며 가진 주 파수는 $100 \mathrm{~Hz} \sim 5 \mathrm{MHz}$ 범위를 측정한 결과 공진 주파수 가 가장 뚜렷하게 나타나는 $200 \mathrm{KHz} \sim 600 \mathrm{KHz}$ 로 설정 하였다. 하중은 변위제어 방법을 사용하였으며 수동으로 가력하여 각 하중단계별로 임피던스 신호를 계측하였다. 계측된 임피던스를 그래프로 보기위하여 PC에 LabVIEW 프로그램을 설치하여 확인하였다.

\subsection{FRP로 보강된 콘크리트 보의 손상 모니터링}

\subsection{1 실험개요}

보수 및 보강으로 인한 파괴모드의 변화는 구조물의 파 괴 경향을 파악하기 어렵게 하는 중요한 변수가 된다. 특 히, FRP보강공법이 적용된 콘크리트 보는 외부에 에폭시 등으로 접착된 $\mathrm{FRP}$ 로 인하여 휨파괴 및 전단파괴 외에 부착파괴가 추가적으로 발생하게 되며 이러한 부착파괴 가 전체거동을 지배하게 되는 경우가 대부분이다.

본 논문에서는 이러한 국부적인 손상 파악에 유리한 PZT센서를 이용한 임피던스 기법을 통하여 콘크리트 균 열과 CFRP 박리 모니터링에 대한 적용성을 확인하였고, 계측기법과 손상평가 방법에 대해 고찰해 보았다. 또한, $\mathrm{CFRP}$ 로 보강된 콘크리트 보에 적용하여 정적 실험을 수 행하여 손상 단계별 임피던스 계측 및 분석을 통하여 구 조물의 취약부 및 전체 파괴거동을 평가해 보았다.

\subsection{2 실험결과}

콘크리트에 부착된 PZT센서에서의 임피던스 계측은 하중을 가하지 않은 무손상 상태를 포함하여 총 6단계로 계측하였다. 콘크리트 보의 중앙부인 하중재하 부분에 초 기 균열이 발생하였으며 $\mathrm{CFRP}$ 탈락 이전에는 미소균열 만이 발생하였고 CFRP 탈락 이후 급격히 균열 폭이 커졌 다. 하중재하에 따른 균열상태의 변화를 Table 5 에 나타 내었다. 하중 $22.54 \mathrm{kN}$ (균열하중) 에서 콘크리트 보 중앙 부 하중재하 부분에 $0.1 \mathrm{~mm}$ 정도의 미소균열 2 개소 발생 하기 시작했고, 하중 $38.2 \mathrm{kN}$ 에서는 $0.1 \mathrm{~mm}$ 정도의 미소 균열이 3 개소 더 발생하였고 기존 균열은 $0.15 \mathrm{~mm}$ 정도 로 발전하였다. 그리고 하중 $58.8 \mathrm{kN}$ 에서 추가적인 균열 은 발생하지 않고 기존 균열의 발전도 미미하였다. 이후 에 하중 $76.44 \mathrm{kN}$ (CFRP 탈락)에서 CFRP가 탈락되면서 콘크리트 보 중앙부의 균열이 $0.5 \mathrm{~mm}$ 정도로 진전하였고 미소균열도 다수 발생하였고, $\mathrm{CFRP}$ 탈락 이후 인장 철근 이 항복하면서 균열이 계속 진전했다.

콘크리트에 부착된 PZT센서에서 계측된 임피던스 신 호는 Fig. 2 와 같이 균열이 진전됨에 따라 변화량이 더 커져 균열의 발생이 임피던스 신호의 변화에 영향을 줌을 확인할 수 있었다. 가한 하중이 $22.54 \mathrm{kN}$ 에서 초기 균열 이 발생하였을 때 특히 임피던스 신호의 변화가 커졌으며

Table 5 Concrete crack conditions by load levels

\begin{tabular}{c|c|c|c|c|}
\hline $\begin{array}{c}\text { Levels } \\
\text { (Crack occurrence) }\end{array}$ & & Crack conditions \\
\hline $38.2 \mathrm{kN}$ & & & \\
\hline
\end{tabular}




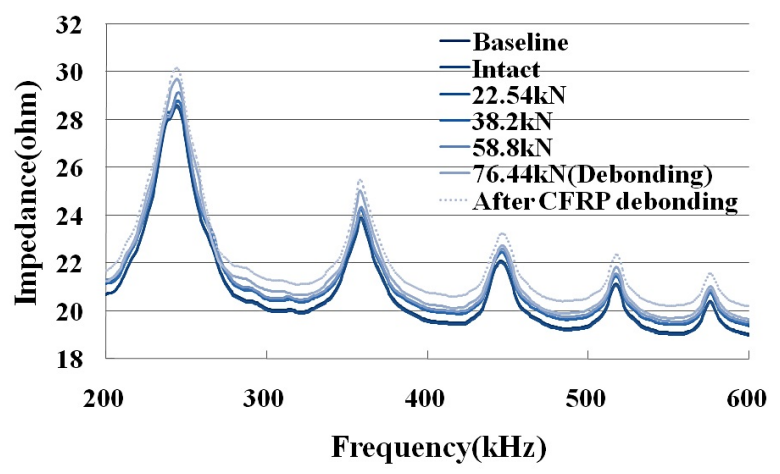

Fig. 2 Impedance measured at C-PZT\#1

Table 6 RMSD(\%) of impedance data at C-PZT\#1

\begin{tabular}{c|c|c}
\hline Scenario & $\begin{array}{c}\text { RMSD(Root Mean } \\
\text { Square Diviation) }\end{array}$ & $\begin{array}{c}\text { Damage evaluations } \\
\text { (variate/intact) }\end{array}$ \\
\hline baseline & $0 \%$ & 1 \\
\hline intact & $0.323 \%$ & 5.750 \\
\hline $\begin{array}{c}22.54 \mathrm{kN} \\
\text { (Crack occurrence) }\end{array}$ & $1.856 \%$ & 6.014 \\
\hline $38.2 \mathrm{kN}$ & $1.945 \%$ & 7.223 \\
\hline $58.8 \mathrm{kN}$ & $2.336 \%$ & 10.302 \\
\hline $\begin{array}{c}76.44 \mathrm{kN} \\
\text { (CFRP debonding) }\end{array}$ & $3.331 \%$ & 17.373 \\
\hline $\begin{array}{c}\text { After CFRP } \\
\text { debonding }\end{array}$ & $5.618 \%$ & \\
\hline
\end{tabular}

CFRP 탈락 이후 균열 폭이 급격히 증가함에 따라 임피던 스 신호 역시 변화 폭이 커짐을 확인할 수 있었다.

Fig. 2와 Table 6에 콘크리트 중앙부에 가장 가까운 $\mathrm{C}-\mathrm{PZT} \# 1$ 센서에서 계측된 임피던스 신호와 RMSD에 의한 손상지수를 나타내었다. C-PZT\#2, C-PZT\#3, $\mathrm{C}-\mathrm{PZT} \# 4$ 에서 계측한 임피던스 신호 역시 콘크리트 균 열을 반영하여 변화를 나타내었고 콘크리트 중앙부의 주 요 균열에서의 거리가 멀어질수록 임피던스 변화량과 손 상지수는 작게 나타났다.

\subsection{3 $\mathrm{CFRP}$ 부착파괴 모니터링 결과}

$\mathrm{CFRP}$ 판에 부착된 $\mathrm{PZT}$ 센서에서의 임피던스 계측은 하중을 가하지 않은 무손상 상태(Intact)를 포함하여 총 6단계로 계측하였다. 콘크리트 균열 모니터링 실험과 마 찬가지로 하중 단계별로 임피던스 신호를 계측하였으며, 다른 부분은 $\mathrm{CFRP}$ 탈락 이전과 이후의 임피던스 신호를 계측하여 비교·분석 하였다. $\mathrm{CFRP}$ 판에 부착된 임피던스 신호는 초기에는 $\mathrm{CFRP}$ 판의 탈락이 보의 왼쪽 끝단에서

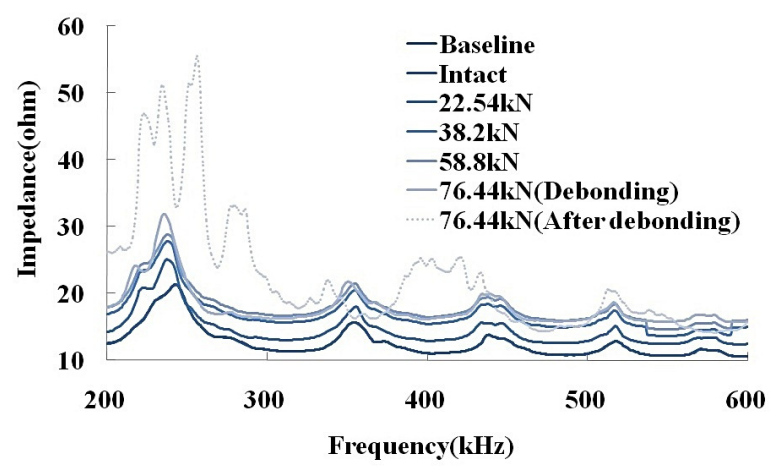

Fig. 3 Impedance measured at F-PZT\#3

Table 7 RMSD(\%) of impedance data at F-PZT\#3

\begin{tabular}{c|c|c}
\hline Scenario & $\begin{array}{c}\text { RMSD(Root Mean } \\
\text { Square Diviation) }\end{array}$ & $\begin{array}{c}\text { Damage evaluations } \\
\text { (variate/intact) }\end{array}$ \\
\hline baseline & $0 \%$ & 1 \\
\hline intact & $0.931 \%$ & 16.753 \\
\hline $\begin{array}{c}22.54 \mathrm{kN} \\
\text { (Crack occurrence) }\end{array}$ & $15.601 \%$ & 20.254 \\
\hline $38.2 \mathrm{kN}$ & $18.856 \%$ & 26.247 \\
\hline $58.8 \mathrm{kN}$ & $24.436 \%$ & 32.565 \\
\hline $\begin{array}{c}76.44 \mathrm{kN} \\
\text { (CFRP debonding) }\end{array}$ & $30.318 \%$ & 102.568 \\
\hline $\begin{array}{c}76.44 \mathrm{kN} \\
\text { (After CFRP } \\
\text { debonding) }\end{array}$ & $95.514 \%$ & \\
\hline
\end{tabular}

발생했음에도 불구하고 콘크리트 보의 중앙부에서 가장 많은 변화가 나타났다. 이것은 $\mathrm{CFRP}$ 판의 변형 및 균열 로 인한 $\mathrm{CFRP}$ 의 박리의 발생의 영향으로 임피던스 신호 가 변화한 것으로 판단할 수 있다.

본 실험에서의 $\mathrm{CFRP}$ 판에 부착된 $\mathrm{PZT}$ 센서에서 $76.44 \mathrm{kN}$ 이전에 계측된 임피던스 신호의 변화는 CFRP 박리 보다는 CFRP 판의 변형률에 따른 변화라고 판단된 다. Fig. 3은 콘크리트 보의 중앙부에 부착된 $\mathrm{F}-\mathrm{PZT} \# 3$ 에서 계측한 임피던스 신호를 나타낸 것이다. CFRP 판 탈락 이전에는 임피던스 신호의 크기가 일정하게 증가함 을 알 수 있었다. 콘크리트 보 실험체는 $76.44 \mathrm{kN}$ 에서 $\mathrm{CFRP}$ 판 탈락의 징후를 보였고 $\mathrm{CFRP}$ 탈락 직전에 계측 한 임피던스 신호는 이전의 임피던스 신호의 변화와는 다 른 양상을 보였다. 임피던스의 크기뿐 아니라 공진주파수 와 임피던스 신호의 형태 또한 변화를 보였다. CFRP 판 탈락 이후의 임피던스 신호는 Fig. 3과 같이 이전과 전혀 다른 모양의 임피던스 신호가 계측되었다. 이것은 $\mathrm{CFRP}$ 
탈락 시 PZT센서가 손상을 입어 PZT센서의 공진 주파 수가 변화하여 발생한 결과로 판단된다. Fig. 4는 CFRP 판의 탈락이 발생한 위치인 $\mathrm{F}-\mathrm{PZT} \# 6$ 에서 계측한 임피 던스 신호를 나타낸 것이다. 하중이 증가할수록 $\mathrm{CFRP}$ 의 변형에 따라 임피던스 신호는 일정하게 변화함을 확인할 수 있었고, $\mathrm{CFRP}$ 판 탈락 직전에 임피던스 신호의 변화 가 크게 증가하는 것으로 $\mathrm{CFRP}$ 박리가 발생하였음을 확 인할 수 있다.

\section{3 구조물 손상평가 및 실 구조물 적용에 대한 고찰}

임피던스 기법은 국부적인 손상 등으로 인한 상태변화 감지를 바탕으로 구조물의 건전성을 모니터링하는 기법 으로 아래와 같이 $\mathrm{CFRP}$ 보강 $\mathrm{RC}$ 보의 손상 상태 및 거동 예측이 가능하다.

Fig. 5는 CFRP 보강 RC보의 균열양상, Fig. 6과 Fig. 7은 각각 콘크리트와 $\mathrm{CFRP}$ 보강판에 부착한 $\mathrm{PZT}$ 센서에 서 계측한 임피던스를 RMSD로 분석한 결과이다. $\mathrm{CFRP}$ 보강 $\mathrm{RC}$ 보는 $22.5 \mathrm{kN}$ 에서 1번과 2번 균열이 발생하였고 $\mathrm{C}-\mathrm{PZT} \# 1, \mathrm{C}-\mathrm{PZT} \# 2, \mathrm{C}-\mathrm{PZT} \# 3, \mathrm{C}-\mathrm{PZT} \# 4$ 의 손

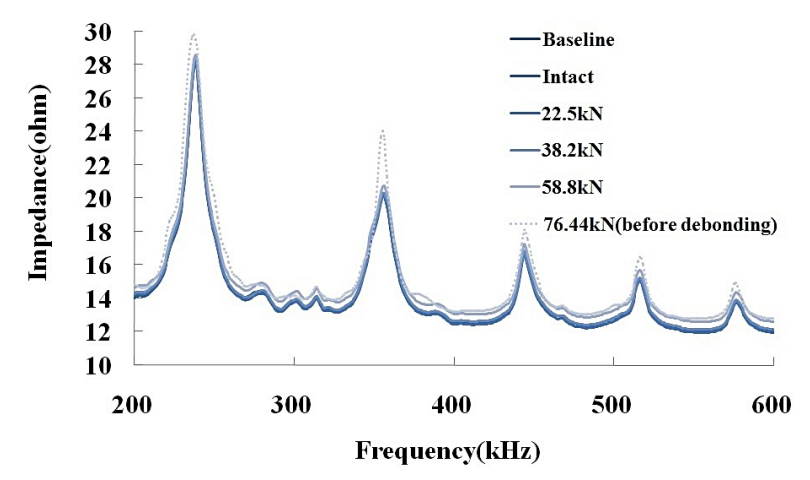

Fig. 4 Impedance measured at F-PZT\#6

Table 8 RMSD(\%) of impedance data at F-PZT\#6

\begin{tabular}{c|c|c}
\hline Scenario & $\begin{array}{c}\text { RMSD(Root Mean } \\
\text { Square Diviation) }\end{array}$ & $\begin{array}{c}\text { Damage evaluations } \\
\text { (variate/intact) }\end{array}$ \\
\hline baseline & $0 \%$ & 1 \\
\hline intact & $0.931 \%$ & 9.237 \\
\hline $\begin{array}{c}22.54 \mathrm{kN} \\
\text { (Crack occurrence) }\end{array}$ & $8.602 \%$ & 12.962 \\
\hline $38.2 \mathrm{kN}$ & $12.071 \%$ & 22.130 \\
\hline $58.8 \mathrm{kN}$ & $20.608 \%$ & 44.719 \\
\hline $\begin{array}{c}76.44 \mathrm{kN} \\
\text { (Before CFRP } \\
\text { debonding) }\end{array}$ & $31.644 \%$ & \\
\hline
\end{tabular}

상지수는 각각 $5.750,2.353,2.115,1.230$ 으로 나타나 C-PZT\#1 왼쪽 부분에 균열이 발생하였음을 확인할 수 있다.

또한 Fig. 6의 손상지수를 바탕으로 $38.2 \mathrm{kN}$ 에서 4 번 균열, $58.8 \mathrm{kN}$ 에서 6 번균열 그리고 $76.44 \mathrm{kN}$ 에서 8 번 균 열이 발생하였음을 예측할 수 있다. CFRP 탈락 이후 균

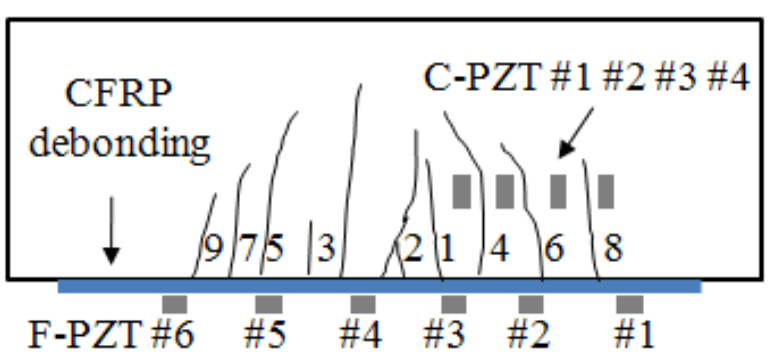

Fig. 5 Crack appearance of CFRP strengthened concrete beam

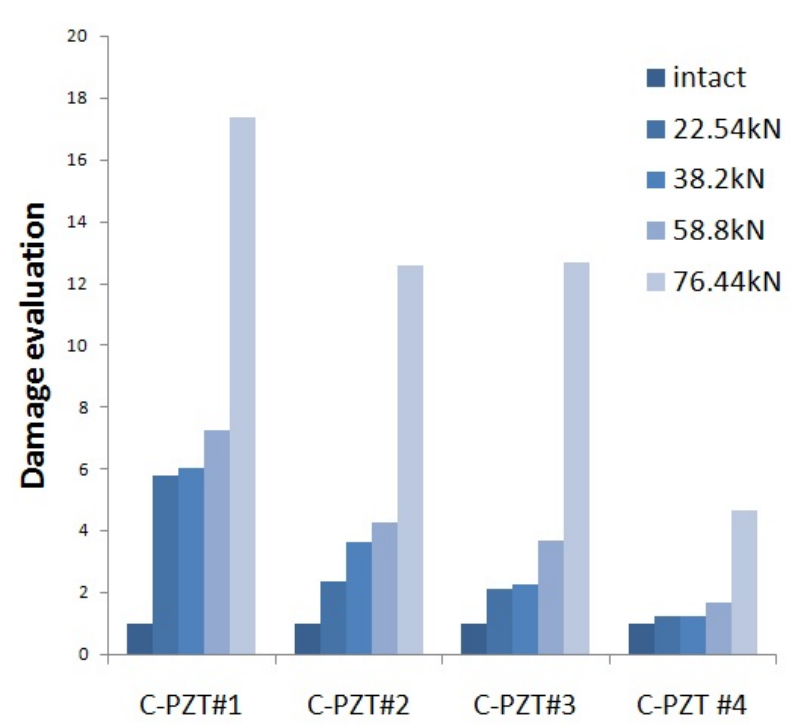

Fig. 6 Damage evaluations of C-PZT sensors bonding on concrete

Table 9 Damage evaluations of C-PZT sensors bonding on concrete beam

\begin{tabular}{c|c|c|c|c}
\hline \multirow{2}{*}{ Scenario } & \multicolumn{4}{|c}{ Damage evaluations } \\
\cline { 2 - 5 } & C-PZT\#1 & C-PZT\#2 & C-PZT\#3 & C-PZT \#4 \\
\hline intact & 1 & 1 & 1 & 1 \\
\hline $\begin{array}{c}22.54 \mathrm{kN} \\
(\text { Crack occurrence) }\end{array}$ & 5.750 & 2.353 & 2.115 & 1.230 \\
\hline $38.2 \mathrm{kN}$ & 6.014 & 3.598 & 2.235 & 1.234 \\
\hline $58.8 \mathrm{kN}$ & 7.223 & 4.236 & 3.658 & 1.654 \\
\hline $\begin{array}{c}76.44 \mathrm{kN} \\
\text { (Before CFRP } \\
\text { debonding) }\end{array}$ & 17.373 & 12.548 & 12.658 & 4.658 \\
\hline
\end{tabular}




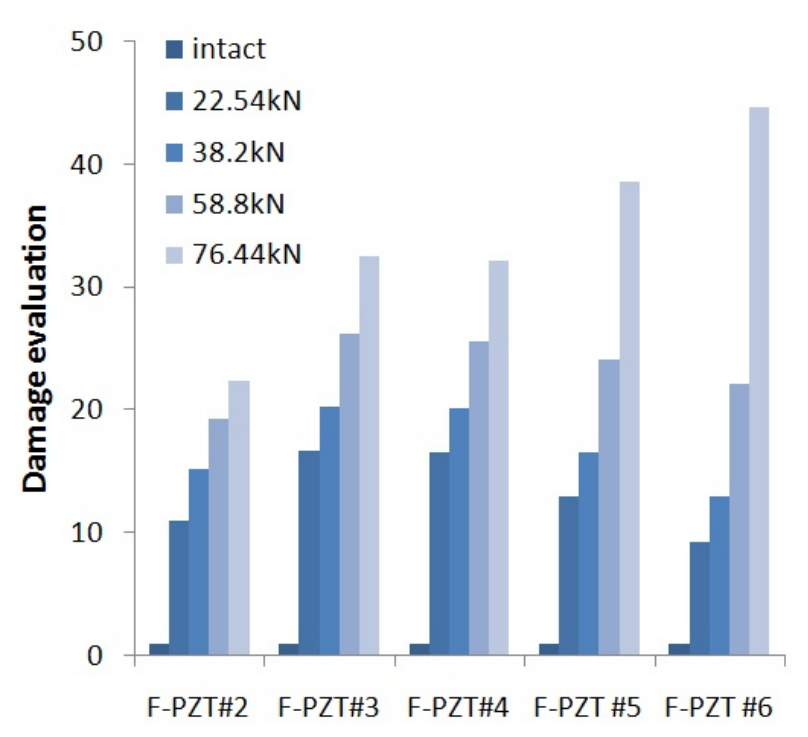

Fig. 7 Damage evaluations of F-PZT sensors bonding on CFRP

Table 10 Damage evaluations of F-PZT sensors bonding on CFRP

\begin{tabular}{c|c|c|c|c|c}
\hline \multirow{2}{*}{ Scenario } & \multicolumn{5}{|c}{ Damage evaluations } \\
\cline { 2 - 6 } & F-PZT\#2 & F-PZT\#3 & F-PZT\#4 & F-PZT\#5 & F-PZT\#6 \\
\hline intact & 1 & 1 & 1 & 1 & 1 \\
\hline $\begin{array}{c}22.54 \mathrm{kN} \\
\text { (Crack } \\
\text { occurrence) }\end{array}$ & 10.994 & 16.753 & 16.524 & 12.995 & 9.237 \\
\hline $38.2 \mathrm{kN}$ & 15.244 & 20.254 & 20.125 & 16.608 & 12.962 \\
\hline $58.8 \mathrm{kN}$ & 19.250 & 26.247 & 25.658 & 24.189 & 22.13 \\
\hline $\begin{array}{c}76.44 \mathrm{kN} \\
\text { (Before CFRP } \\
\text { debonding) }\end{array}$ & 22.459 & 32.565 & 32.214 & 38.642 & 44.719 \\
\hline
\end{tabular}

열이 급 진전되면서 각각의 PZT센서의 손상지수 또한 급 격하게 증가하였으며 C-PZT\#1의 손상지수의 변화량이 현저하게 나타난 것을 바탕으로 보 지간 중앙부에 균열이 집중되어 휨 파괴 형상을 보임을 예측할 수 있다.

Table 10에서 보듯이 $22.54 \mathrm{kN}$ 의 초기 균열이후에 $\mathrm{CFRP}$ 의 변형의 영향으로 $\mathrm{CFRP}$ 에 부착된 $\mathrm{PZT}$ 의 손상 지수가 전체적으로 증가하였고, $\mathrm{F}-\mathrm{PZT \# 3,} \mathrm{F}-\mathrm{PZT} \# 4$ 의 손상지수의 변화가 크게 나타나 지간중앙에 균열이 발 생하면서 CFRP 박리가 발생하였음을 예측할 수 있다. $\mathrm{F}-\mathrm{PZT} \# 1$ 의 손상지수는 하중이 증가함에 따라 큰 변화 가 없어 CFRP 변형이외의 박리는 거의 발생하지 않은 것 으로 판단되며, CFRP 탈락이 발생한 부분에 부착된 $\mathrm{F}-\mathrm{PZT} \# 6$ 의 손상지수는 하중이 증가함에 따라 뚜렷한 증가를 보였으며 $\mathrm{CFRP}$ 탈락 직전인 $76.44 \mathrm{kH}$ 의 하중이 가해졌을 때 신호의 급격한 증가를 보여 $\mathrm{CFRP}$ 탈락의 징 후를 확인할 수 있었다.

\section{4. 결 론}

본 논문에서는 PZT센서를 이용한 임피던스 기법을 $\mathrm{CFRP}$ 판 보강 $\mathrm{RC}$ 보의 균열 및 박리 손상 모니터링에 적 용하기 위한 실험을 수행해 다음과 같은 결론을 얻었다.

(1) 구조물이 손상 등의 이유로 상태가 변하면 그 물성 이 변하고 구조물의 고유주파수가 변하게 된다. 이로 인해 구조물-PZT센서의 전기-역학적 임피던스 및 공진주파수가 변하게 되며 이러한 특성은 콘크리트 와 $\mathrm{CFRP}$ 의 재료에서도 적용이 가능했고 $\mathrm{PZT}$ 센서 를 이용한 임피던스 기법을 사용해 CFRP 판 박리를 확인할 수 있었다.

(2) 구조물의 가진 주파수 설정은 임피던스 기법에서 중 요하며 구조물 특성이 잘 나타나는 공진주파수가 존 재하는 구간을 설정해야 한다. 본 논문의 실험 결과 $\mathrm{CFRP}$ 는 $200 \mathrm{kHz} \sim 600 \mathrm{kHz}$ 사이의 범위에서 공진주 파수가 뚜렷하게 나타났고 $\mathrm{CFRP}$ 박리 모니터링이 가능하였다.

(3) 본 논문에서는 여러 개의 PZT센서의 손상지수를 바 탕으로 $\mathrm{CFRP}$ 판 보강 $\mathrm{RC}$ 보의 손상 감지와 거동 예 측을 수행하였다. 하지만 임피던스 기법은 구조물의 재료특성, 형상 및 질량 그리고 온도, 손상의 종류 등 다양한 인자에 따라 임피던스 신호의 변화양상이 달 라지기 때문에 정량적 평가 기준을 확립하기 어렵다. 따라서 실 구조물 적용을 위해서는 대상 구조물의 거동을 미리 파악하여 위험 구간에서의 국부적인 손 상 모니터링을 통하여 구조물의 건전성을 파악하는 것이 효율적인 방법이다.

\section{감사의 글}

본 연구는 국토해양부 u-City 석박사과정 지원사업에 의해 수행되었으며 전폭적인 지원에 감사드립니다.

\section{참고문헌}

1. 김대민, "압전소자를 이용한 콘크리트 구조물의 손상추정법에 관한 연구”, 경북대학교 대학원, 석사학위논문, 2008.

2. 류성찬, 김주원, 이창길, 박승희, 박선규, " $\mathrm{CFRP}$ 보강 콘크리 트 구조물의 PZT센서 기반 구조 건전성 모니터링”, 한국구조 물진단학회, 제14권 5호, 2010, pp.72-78.

3. 박승희, 윤정방, 노용래, Ahmad Sohaib, "토목구조 부재의 $\mathrm{PZT}$ 기반 상시 비파괴 검사 기법”, 한국비파괴검사학회, 춘 
계학술대회 논문집, 2005, pp.167-174.

4. 이정미, "PSC 거더의 긴장력 변화에 따른 휨진동 응답 및 정 착부 임피던스 응답 특성에 관한 실험적 연구”, 부경대학교 대학원, 석사학위논문, 2008 .

5. 이진학, 박승희, 윤정방, 노용래, "임피던스 계측을 통한 구조 물의 손상 평가”, 한국구조물진단학회, 봄학술발표회 논문집, 2004, pp.517-522.

6. 홍용, "스마트 재료를 이용한 손상 탐지 기법과 구조물의 건 전성 평가에 관한 연구”, 전북대학교 대학원, 박사학위논문, 2009.

7. A. N. Zagrai and V. Giurjutiu, "Electro-Mechanical Impedance Method for Crack Detection in Thin Wall Structures", 3rd International Workshop of Structural Health Monitoring, 2001, pp.12-14.

8. Bhalla, S., Naidu, A.S.k, C. K., "Influence of structure actuator Interaction and temperature on piezoelectric signatures for NDE”, Proc. ISSS-SPIE 2002 International Conference on Smart Materials Structures and Systems. 2002, pp.50-62.

9. Chen Liang, Fanping Sun and Craig A Rogers, "Electro- mechanical impedance modeling of active material systems", Smart Materials \& Structures, Vol. 5, 1996, pp.171-186.

10. Farrar, C. R., Duffey, T. A., Doebling, S. W. and Nix, D. A., "A statistical pattern recognition paradigm for vibration-based structural health monitoring", 2nd Int. Workshop on Structural Health Monitoring, 1999, pp.764-773.

11. Giurgiutiu, V. Reynolds, A. and Rogers, C. A., Experimental Investigation of $\mathrm{E} / \mathrm{M}$ Impedance Health Monitoring for Spot-welded Structural Joints, J. Intell. Mater. Syst. Struct., 10,, 1999, pp.802-812.
12. Hoon Sohn, Seung Dae Kim, Chi Won in, Kelly E. Cronin and Kent Harries, "Debonding Monitoring of CFRP Strengthened RC Beam without Reference Date nor Prior Decision Boundaries", The 4th International Conference on Earthquake Engineering, 2006, pp.12-13

13. Kessler, S. S., "Piezoelectric-Based In-Situ Damage Detection of Composite Materials for Structural Health Monitoring Systems”, 1-200, MIT, Ph.D thesis, 2002.

14. Liang, L., Sun, F. P. and Rogers, C. A., "Coupled electro-mechanical analysis of adaptive material systems determination of the actuator power consumption and system energy transfer", Journal of Intelligent Material Systems and Structures. 5, 1994, pp.12-20.

15. Park. G, Sohn. H, C. R. and Inman, D. J., "Overview of Piezoelectric Impedance-Based Health Monitoring and Path Forward", Shock and Vibration Digest, Vol. 35, No. 6, 2003, pp.451-463.

16. Park, G., Cudney, H. and Inman, D. J., "Impedance-based health monitoring of civil structural components", The Shock and Vibration Digest. 33(4), 2001, pp.269-280.

17. Sohn, H. and Farrar C. R., "Damage diagnosis using time series analysis of vibration signals", Smart Materials and Structures, 10, 2001, pp.446-451.

CFRP 보강공법은 구조물에 내하력을 증가시키기 위해 사용되고 있는데 실제 교량에 적합하고 연구 활용성이 좋다. 하지만, $\mathrm{CFRP}$ 로 보강된 콘크리트 보에서 휨파괴와 전단파괴 뿐만 아니라 부착파괴 또한 추가적으로 발생하게 된다. 이러한 CFRP 부착 파괴는 취성파괴를 유발하게 된다. 따라서 이러한 CFRP로 보강된 콘크리트보 박리에 대한 모니터링은 매우 중요한 의미를 갖는 다. 본 논문에서는 국부적인 손상 파악에 유리한 PZT센서를 이용한 임피던스 기반 손상검색 방법을 사용하여 CFRP로 보강된 콘크리트보에서 박리 모니터링에 대한 적용가능성을 검증해 보았다.

핵심 용어 : 콘크리트 균열, $\mathrm{CFRP}$ 부착파괴, PZT센서, 임피던스 기법 